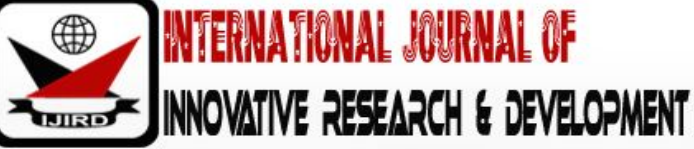

ISSN 2278 - 0211 (Online)

\section{Economic Efficiency Analysis of Rice Farming That Returns Straw Compared to Those That Do Not Return Straw to Rice Fields in Subang Regency, West Java, Indonesia}

\author{
Handoko \\ SP, Department of Students of the Master Program in Agricultural Economics, Padjajaran University, \\ Indonesia \\ Lies Sulistyowati \\ Lecturer, Department of the Master Program in Agricultural Economics, Padjajaran University, Indonesia \\ Elly Rasmikayati \\ Lecturer, Department of the Master Program in Agricultural Economics, Padjajaran University, Indonesia
}

\begin{abstract}
:
The potential of harvested rice straw in Subang Regency which is very large should not be burned, but used as compost to meet half of the needs of chemical fertilizers. Thus the efficiency of farmer farming can be increased due to the transition and reduction in the cost of purchasing inorganic fertilizers. The difference in attitude is caused by differences in farmers' perception of the technology of straw restoration. This study aims to describe find out whether there are differences in the level of technical, allocative and economic efficiency between farmer that returns straw to paddy fields and which does not return. Research was conducted on 228 sample farmers in the Binong Subdistrict, Pusakanegara, and Patokbeusi SubDistrict, West Java. The research design uses quantitative by using sample withdrawals multi stage cluster sampling. Data collection with interview techniques with questionnaire instruments. Data were analyzed using production functions stochastic frontier cobb douglas. The results of the analysis concluded the level of technical efficiency of farmers who return hay to rice fields by $93 \%$ and those who do not return $95 \%$, the allocative efficiency level of farmers who return hay to paddy fields by $73 \%$ and those who do not return $59 \%$, and the level of economic efficiency of farmers who return straw to rice fields by $67 \%$ and those that do not return by $56 \%$. The level of allocative and economic efficiency of farmers who return straw to paddy fields is higher than those who do not.
\end{abstract}

Keywords: Cobb Douglas function, straw of rice, efficiency

\section{Introduction}

Subang Regency is a district that has the third largest rice field area in West Java after Indramayu and Karawang, and is also the third largest contributor of rice production in West Java.The area of rice fields in 2016 recorded an area of 84,570 hectares or $41.22 \%$ of the total area of Subang Regency. While the amount of rice production from rice fields and paddy fields in Subang Regency in 2015 was 1,153,807 tons.While the data on production and productivity of rice in Subang Regency are as follows:

\begin{tabular}{|c|c|c|c|c|c|}
\hline \multirow{2}{*}{\begin{tabular}{c} 
Description \\
\cline { 2 - 6 }
\end{tabular}} & 2011 & 2012 & 2013 & 2014 & 2015 \\
\hline $\begin{array}{c}\text { Production } \\
\text { (tons) }\end{array}$ & 1.180 .594 & 1.149 .147 & 1.204 .829 & 1.147 .650 & 1.153 .807 \\
\hline \multicolumn{6}{|c|}{ Production Development } \\
\hline Tons & -31.447 & 55.682 & -57.179 & 6.157 \\
\hline$\%$ & 2,66 & 4,85 & 4,75 & 0,54 \\
\hline Productivity (ql/ ha) & 66,12 & 67,16 & 67,86 & 64,99 & 70,44 \\
\hline \multicolumn{6}{|c|}{ Productivity Development } \\
\hline ql/ha & 1,04 & 0,7 & $-2,87$ & 5,45 \\
\hline & 1,57 & 0,01 & 4,23 & 8,39 \\
\hline
\end{tabular}

Table 1: Production (Tons) and Productivity (Ql/ Ha) of Rice Fields and Paddy Fields in

Subang Regency between 2011 - 2015

Source: BPS Subang Regency, 2016 
The development of rice production and productivity in Subang Regency as shown in Table 1 is unstable, the rice production in Subang Regency in 2015 reached 1,153,807 tons of GKP.Compared to 2014, rice production in 2015 experienced an increase of 6,157 tons of GKP or an increase of $0.54 \%$.The increase in production was due to an increase in rice productivity of $5.45 \mathrm{ql} /$ ha or around $8.39 \%$ compared to 2014 .

Increased productivity from year to year is unstable and even tends to fluctuate.These productivity conditions can be increased through efforts to intensify or improvement in technology.This effort is more likely to be done considering the increase in production through extensification or expansion of rice fields is becoming inefficient.The limitations of the government budget for the opening of irrigated land and the high competition for land use for nonagricultural activities have an impact on the increasing cost of rice production through the expansion of rice fields.The alternative that needs to be considered is to increase land productivity through efficiency.

Efforts to increase rice production through technical efficiency is becoming the right choice.The technical efficiency of rice farming in Indonesia is thought to still be improved, because the efficiency level of farming according to previous research is in the range of $50 \%$ to $90 \%$.The level of technical efficiency of rice farming varies between regions with a range of $64 \%$ to $80 \%$ (Sumaryanto et al, 2001).Sumaryanto's research, et al (2003) shows that the average level of technical efficiency of farming is 76\%.This is supported by the results of Nunung Kusnadi's research (2011) showing the value of technical efficiency of rice farming is in the range of $59 \%$ to $87 \%$.

One of the causes of the degradation in rice production in Indonesia is that most of the rice fields have been degraded, which among others is characterized by low organic matter content.The results of the Agricultural Research and Development Agency's research shows that the fertility rate of rice fields in Indonesia is decreasing, around 65\% of the 5 million hectares of irrigated rice fields have organic material content of less than $2 \%$ while in normal conditions fertile rice fields usually contain at least 3\% organic material (Suriadikarta and Simanungkalit, 2006).

The cause of the decrease in the level of organic matter in rice fields in Indonesia, among others (1) farmers only use inorganic fertilizers.Information from the Minister of Agriculture Regulation (2011) intensive use of inorganic fertilizers that has lasted more than thirty years has caused soil sickness, soil fatigue, and inefficiency in the use of inorganic fertilizers;(2) rice straw is transported out of the field both for use as animal feed and as raw material for making paper;and (3) farmers' habits of transporting straw outside the field or burning waste harvested straw (Rosinta $\mathrm{Br}$ Sitepu, 2013).

Continuous use of inorganic fertilizers will cause the soil to become solid / hardened (decreased soil porosity) and unresponsive to inorganic fertilizers, so that no matter how much soil is given inorganic fertilizer the results are still not optimal.Hardened agricultural land also has an impact on plant growth, which is the limited spread of roots and obstruction of oxygen supply to the roots resulting in not optimal root function, which in turn reduces crop productivity (Safitri, 2010).

The decline in rice yields on rice fields that are continuously cultivated often occurs especially if the straw is transported.The transport of straw at harvest reduces soil fertility because most organic matter and soil nutrients are transported to other places so that in the long run soil fertility will decrease.Returning rice straw or providing organic matter is expected to improve nutrient balance so that the preservation of rice field fertility can be maintained.In Indonesia, straw is burned or transported out of the land for reasons to eliminate difficulties during tillage, control pests and diseases, save energy or for animal feed and for other purposes (Amrah, 2008).

Immersing crop residues (one of which is the return of straw) is one of traditional wisdom (local wisdom) that provides benefits to increase soil organic matter content.In addition, the addition of organic straw material can reduce the use of inorganic fertilizers.Organic matter is needed to maintain soil fertility by maintaining and improving the function of microorganisms in the soil so as to increase the availability of nutrients in the soil also increase the effectiveness of fertilization.Therefore, the management of organic material in rice fields combined with inorganic fertilizer is needed to increase rice productivity.The addition of organic matter can increase fertilization efficiency so that the growth and yield of rice can increase.

According to Arafah and M. Sirappa (2002), the return of straw can increase the number of pithy panicles, reduce the percentage of empty grains and increase the weight of harvested dry grain.This is confirmed by the opinion of Arya Sudiadnyana (2012) that the increase in grain production due to the use of straw may be caused by one of the following:(1) increase in supply $\mathrm{N},(2)$ appropriate release pattern $\mathrm{N}$, (3) increase in supply $\mathrm{K}$ (4) increase in supply of other nutrients, (5) improvement of soil structure.

This study aims to determine whether there are differences in the level of technical, allocative, and economic efficiency between farmers who return straw to rice fields with farmers who do not return straw.

\section{Research Methods}

Research design uses quantitative design. The data used in the study are primary data and secondary data, both in the form of qualitative data and quantitative data.Primary data was collected from rice farmers in Cicadas Village and Nangerang in Binong Subdistrict, Tambakjati Village and Jatiragas Hilir in Patokbeusi Subdistrict, Patimban Village and Kotasari in Pusakagara Subdistrict, Subang Regency. This primary data was obtained through direct interviews using a prepared questionnaire. Secondary data came from the Central Bureau of Statistics (BPS), the results of previous research, the internet, the Agriculture Office of the Subang Regency, and the UPTD for Agricultural Management of the Subang Regency.Subang Regency was chosen as the object of research because it has the third largest rice field area in West Java with an area of 84,570 hectares which of course has a large potential of straw-producing while the selection of Binong, Patokbeusi and Pusakanagara Subdistricts through a random sampling process from 30 subdistricts in Subang Regency. The sampling method used is multi stage cluster sampling. Researchers in this case determined $58 \%$ as the basis for 
determining the number of samples of farmers who returned straw to paddy fields.To determine the sample size in a tertiary sample unit, it is carried out with proportional allocation. This is done using the Slovin formula. The total sample was 228 respondent farmers. The analytical method used in this study uses quantitative. To determine the level of technical, allocative, and economic efficiency of the farmer who returns straw to the rice field and who does not return uses the Cobb-Douglas production function model.

Analysis of the production function is a continuation of the application of regression analysis, which is an analysis that explains the causal relationship (Soekartawi 2002).The stochastic frontier approach can be obtained by two conditions simultaneously namely the factors that influence efficiency and at the same time the inefficiency of farmers. The approach carried out with Frontier Version 4.1 software with an empirical model of the Cobb-Douglas stochastic frontier production function that will be used in this study is formulated in the following equation:

The function model for the production of stochastic frontier Cobb-Douglas rice paddies is as follows:

$\ln Y=\beta 0+\beta 1 \ln X 1+\beta 2 \ln X 2+\beta 3 \ln X 3+\beta 4 \ln X 4+\beta 5 \ln X 5+\beta 6 \ln X 6+\beta 7 \ln X 7+\beta 8 \ln X 8+\beta 9 \ln X 9+\beta 10 \ln X 10+\beta 11 \ln X 11+v i-u i$ Where:

$\mathrm{Y}=$ Total amount of rice production per planting season (tons)

$\mathrm{X} 1=$ Land area (ha)

$\mathrm{X} 2=$ Number of seeds of rice per planting season $(\mathrm{kg})$

$\mathrm{X} 3=$ Amount of urea $(\mathrm{kg})$

$\mathrm{X} 4=$ Amount of ZA fertilizer $(\mathrm{kg})$

$\mathrm{X} 5$ =Amount of SP-36 fertilizer $(\mathrm{kg})$

$\mathrm{X} 6=$ Amount of NPK fertilizer $(\mathrm{kg})$

$\mathrm{X} 7=$ Amount of organic fertilizer $(\mathrm{kg})$

$\mathrm{X} 8=$ Amount of pesticides (liter)

X9 = Amount of ZPT (liter)

$\mathrm{X} 10=$ Amount of POC (liter)

$\mathrm{X} 11=$ Amount of workers per planting season $(\mathrm{HOK})$

$\beta 0=$ Intercept

$\beta \mathrm{j}=$ Estimator parameter coefficient, where $\mathrm{j}=1,2,3, \ldots 11$

$\mathrm{v}_{\mathrm{i}} \quad=$ Random error term

$\mathrm{u}_{\mathrm{i}} \quad=$ Nonnegative error term

The expected parameter sign is $\beta 1, \beta 2, \beta 3, \beta 4, \beta 5, \beta 6, \beta 7, \beta 8, \beta 9, \beta 10, \beta 11>0$. Positive parameter values mean that with increasing inputs in the form of seeds, urea fertilizer, ZA fertilizer, SP-36 fertilizer, NPK fertilizer, organic fertilizer, pesticides, ZPT, POC, and labor, it is expected to increase rice production.The random shock variable vi is an independent random variable and is normally distributed with a mean value of zero and its variance is constant, $\sigma v 2(N 0,2)$ and free from ui. Variable error ui is a variable that describes the inefficiency in production which is assumed to be freely distributed between each observation and the value of vi.Random variables ui cannot be negative and normally distributed with their distribution values ( $\mu i, 2)$ (Coelli et al, 1998).

\subsection{Technical Efficiency Analysis}

Technical efficiency analysis can be measured using the following formula:

$\mathrm{TEi}=\mathrm{E}[\exp (-\mathrm{ui} / \mathrm{Ei}] \mathrm{i}=1,2,3, \ldots, \mathrm{N}$

Where TEi is the i farmer's technical efficiency, $\exp (-u i) / \varepsilon i$ is the expectation value (mean) of ui with the terms $\in \mathrm{i}$, so it is $0<\mathrm{TEi}<1$. The technical efficiency value is used for functions that have a certain number of outputs and inputs (cross section data). The value of technical efficiency of farmers is categorized as quite efficient if it is worth> 70\% (Saptana, 2012).

\subsection{Hypothesis Testing}

Hypothesis testing is carried out to test the output of the production function. The output hypothesis test of the production function was tested for $\beta$ i parameters to determine whether there was any influence of each explanatory variable in the production function model. Hypothesis testing for production factors as follows:

$\mathrm{H}_{0}: \beta_{\mathrm{i}}=0$

$\mathrm{H}_{1}: \beta_{\mathrm{i}} \neq 0$

The null hypothesis means that the coefficients of each variable in the production function model are equal to zero. If the null hypothesis is accepted, each independent / explanatory variable in the model does not have a significant / real effect on rice production.

\section{Results and Discussion}

\subsection{Comparison of Stochastic Frontier Production Functions of Farmers Returning Straw and Not Returning Straw}

The analysis of the production function used is a model of the Cobb-Douglas stochastic frontier production function. Analysis of the production function is used to determine the factors that affect the production function of rice farming that returns straw to the rice fields and which does not return. The Cobb-Douglas stochastic frontier model is carried out through a two-stage process. The first stage uses ordinary least square (OLS) to estimate parameters and production inputs and the second stage uses the maximum likelihood estimated (MLE) method to estimate the overall parameters of production factors, intercepts and variances of both vi and ui error components. The OLS method is tested first to find out 
whether there is a violation of assumptions or not, namely testing multicollinearity, autocorrelation, and heteroskedasticity.OLS testing on all variables found several variables that have a negative coefficient. Negative variables must be avoided and must be positive to fulfill the assumption that the use of the Cobb-Douglas function is in the state of The Law of Diminishing Return wherein each additional input can increase output.

The function of rice production is determined by the use of inputs. Input variables found in rice farming that return straw to paddy fields and those that do not return are land area, seeds, organic fertilizers, inorganic fertilizers, pesticides, ZPT, POC, and labor. Variables that affect inefficiency are the age of the farmer, formal education, farming experience, and farmers' income.

Using the OLS method on a model of multiple linear equations there is often a problem of multiple collinearities, and a serious problem if the variance inflation factor (VIF) value is greater than 10 and will be considered not serious if the VIF value is smaller or equal to 10.This shows that there is no problem of collinearity, so there is no difficulty in evaluating the effect of each independent variable on the variation in the dependent variable.

Rice production of farmers who return straw and who do not return is analyzed separately using the following CobbDouglas stochastic frontier production function model:

where:

$$
\ln Y_{i}=\beta_{0}+\sum_{j=1}^{7} \beta_{j} \ln X_{j_{i}}+v_{i}-u_{i}
$$

$\mathrm{Y}_{\mathrm{i}}$

$X_{1_{i}}$

$X_{2_{i}}$

$X_{3}$

$\mathrm{X}_{4}$

$X_{5 i}$

$X_{6 j}$

$X_{7 i}$

$X_{8 \mathrm{i}}$

$X_{9_{i}}$

$X_{10_{\mathrm{i}}}$

$X_{11_{\mathrm{i}}}$

$\beta_{0}$

$\beta_{\mathrm{j}} \quad=$ Vector parameter of production function $(\mathrm{j}=1,2, \ldots, 11)$

$\mathrm{v}_{\mathrm{i}} \quad=$ Random error term

$\mathrm{u}_{\mathrm{i}} \quad=$ Nonnegative error term

$=$ Rice production output from farmeri $(\mathrm{kg})$

$=$ Rice field area of farmeri (hectares)

$=$ Amount of seeds used by farmer $\mathrm{i}(\mathrm{kg})$

$=$ Amount of urea fertilizer used by farmeri $(\mathrm{kg})$

$=$ Amount of ZA fertilizer used by farmeri $(\mathrm{kg})$

$=$ Amount of NPK fertilizer used by farmeri $(\mathrm{kg})$

=Amount of SP-36 fertilizer used by farmeri $(\mathrm{kg})$

$=$ Amount of organic fertilizer used by farmeri $(\mathrm{kg})$

$=$ Amount of growth stimulating substances (ZPT) used by farmeri(liters)

$=$ Amount of liquid organic fertilizers (POC) used by farmer i (liters)

$=$ Amount of pesticides used by farmeri (liter)

$=$ Amount of labor used by farmer i (HOK)

\begin{tabular}{|c|c|c|c|c|c|c|}
\hline & \multicolumn{3}{|c|}{$\begin{array}{c}\text { Farmers Who Return Straw } \\
(\mathrm{N}=133 \text { Farmers })\end{array}$} & \multicolumn{3}{|c|}{$\begin{array}{l}\text { Farmers Who Do Not Return } \\
\text { Straw (N=95 Farmers) }\end{array}$} \\
\hline & Coef. & Std. Error & $P>|t|$ & Coef. & Std. Error & $P>|t|$ \\
\hline Constant & 3.88841 & 0.08506 & 0.000 & 3.79045 & 0.04362 & 0.000 \\
\hline Ln Land Area (Ln X1) & 0.92139 & 0.03400 & 0.000 & 0.89783 & 0.02292 & 0.000 \\
\hline Ln Seeds (Ln X2) & -0.05795 & 0.05180 & 0.265 & -0.00496 & 0.03112 & 0.874 \\
\hline Ln Urea Fertilizer (Ln X3) & 0.00761 & 0.01657 & 0.647 & 0.00774 & 0.00593 & 0.195 \\
\hline Ln ZA Fertilizer (Ln X4) & 0.01377 & 0.01047 & 0.191 & 0.00468 & 0.00542 & 0.390 \\
\hline Ln NPK Fertilizer (Ln X5) & -0.00341 & 0.01148 & 0.767 & 0.00393 & 0.00455 & 0.390 \\
\hline $\begin{array}{l}\text { Ln SP-36 Fertilizer } \\
\text { (Ln X6) }\end{array}$ & -0.00361 & 0.00446 & 0.420 & -0.00300 & 0.00252 & 0.237 \\
\hline $\begin{array}{l}\text { Ln Organic Fertilizer } \\
\text { (Ln X7) }\end{array}$ & 0.00651 & 0.00911 & 0.476 & -0.00094 & 0.00335 & 0.779 \\
\hline Ln ZPT (Ln X8) & -0.00965 & 0.01129 & 0.395 & 0.00219 & 0.00535 & 0.683 \\
\hline Ln POC (Ln X9) & 0.00229 & 0.00580 & 0.694 & -0.00125 & 0.00309 & 0.687 \\
\hline Ln Pesticide (Ln X10) & -0.00091 & 0.00664 & 0.891 & 0.00149 & 0.00390 & 0.703 \\
\hline Ln Labor (Ln X11) & 0.01985 & 0.05960 & 0.740 & -0.01704 & 0.02536 & 0.503 \\
\hline
\end{tabular}

Table 2: Results of Stochastic Production Frontier (SPF) Parameter Estimation

Using the Maximum Likelihood Method

Based on the results of the stochastik production frontier (SPF) estimation using the maximum likelihood method, the input factors that affect production significantly is only variables of land area (X1), while other farming input factors have no significant effect on the population level.

Table 2 is the result of the estimation of the production function with the MLE method which shows that there is only one variable with a positive and significant coefficient of rice production that return straw to the rice field with those who do not return straw to the rice field, which is the land area.The use of land area has a positive and significant effect 
with the elasticity value of 0.92139 indicating that the addition of $1 \%$ of a land area will increase rice production by $0.92139 \%$ where other factors are considered constant.

Land is one of the factors of production that has a large contribution in farming activities.The land area will determine the scale of the farm. This is consistent with the opinion of Suharyanto et al, (2015) which states that land area is a factor of production that has a large role in increasing production because it affects the scale of farming.

Factors of production input such as amount of rice seeds, amount of urea, amount of SP-36, amount of NPK fertilizer, amount of straw, amount of pesticides, and amount of labor do not have significant results, this is due to no difference in cultivation techniques as well as the number and type of production inputs between those that return straw and those that do not.At the time of the research on straw returns by the new farmer respondents in the second season, this caused the return of straw to not have a real effect on increasing production.

The percentage of straw returns by the farmer respondents is also low (50\%) whereas it is recommended to return all the straw to the rice field. Based on the results of research Arafah, et al (2001) the difference in the percentage of straw given will affect the yield of dry grain harvest obtained.The highest yield of dry harvested grain was obtained with $100 \%$ return of straw and the lowest was on treatment without return of straw.

\subsection{Comparison of Technical Efficiency, Allocative and Farming Economy of Farmers Returning Straw and Not Returning} Straw

Technical efficiency analysis can be measured using the following formula:

$$
\mathrm{TE}_{\mathrm{i}}=\exp \left(-\mathrm{E}\left[\mathrm{u}_{\mathrm{i}} \mid \varepsilon_{\mathrm{i}}\right]\right) ; \mathrm{i}=1, \ldots, \mathrm{n}
$$

whereTE $\mathrm{i}_{\mathrm{i}}$ is the technical efficiency of farmeri, $\exp \left(-\mathrm{E}\left[\mathrm{u}_{\mathrm{i}} \mid \varepsilon_{\mathrm{i}}\right]\right)$ is the expectation value (mean) of $\mathrm{u}_{\mathrm{i}}$ based on value $\varepsilon_{\mathrm{i}}$ that is known, so0 $\leq \mathrm{TE}_{\mathrm{i}} \leq 1$.

The technical efficiency method used in this paper refers to a model of technical inefficiency effects developed by Battese and Coelli (1995) in Coelli (1996).So as to help determine the valueTE $\mathrm{i}_{\mathrm{i}}$ used FRONTIER 4.1 software from the Center for Efficiency and Productivity Analysis (CEPA) developed by Coelli.

The processing results of FRONTIER 4.1 program according to Aigner et al (1977), Jondrow et al (1982) or Greene (1993) in Coelli (1996), will provide an estimated value of variance in the form of parameterization $\sigma^{2}=\sigma_{\mathrm{v}}^{2}+\sigma_{\mathrm{u}}^{2}$ and $\gamma=$ $\sigma_{\mathrm{u}}^{2} / \sigma_{\mathrm{v}}^{2}$. The parameters of this variance can search for values $\gamma$, therefore $0<\gamma<1$. Parameter value $\gamma$ is the contribution of technical efficiency in total residual effects.

Allocative and economic efficiency is obtained through analysis in terms of production inputs that use the applicable input prices at the farmer level.The production function used as the basis of the analysis is the stochastic frontier production function. The stochastic frontier production function is reduced by minimizing the input cost function with the production function in the previous Cobb Douglas function equation, so that the dual frontier (isocost frontier) cost function is obtained.

The results of comparison of farmers' technical, allocative and economic efficiency levels that return straw and which do not return are shown in Table 3 below:

\begin{tabular}{|c|c|c|c|}
\hline \multirow{2}{*}{ Description } & \multicolumn{3}{|c|}{ Efficiency } \\
\cline { 2 - 4 } & Technical & Allocative & Economic \\
\hline Farmers returning straw (in\%) & 93 & 73 & 67 \\
\hline $\begin{array}{c}\text { Farmers who do not return straw } \\
\text { (in\%) }\end{array}$ & 95 & 59 & 56 \\
\hline
\end{tabular}

Table 3: Comparison of Technical, Allocative, and Economic Efficiency of Rice

Farming That Return Straw and Do Not Return Straw

The results of technical efficiency analysis using frontier production function model shows that in general the average level of technical efficiency achieved by rice farmers who return straw to rice fields is $93 \%$ while in rice farming farmers who do not return straw to rice fields are $95 \%$ which means that both the farming system has been technically efficient.Referring to the opinion of Coelli et al (1998) that a farm is said to be efficient if its efficiency is greater than or equal to $70 \%$.The average level of technical efficiency when viewed from the highest percentage of achievement level of efficiency ( $90 \%-100 \%$ efficiency interval), the highest achievement of efficiency is for farmers who do not return straw to rice fields, in which get $93 \%$, while rice farmers who return straw get $86 \%$, so it can be concluded that farmers in rice farming who do not return straw are more technically efficient than farmers in rice farming who return straw to rice fields.The results of this study are in line with the results of Nurani's research (2014), Yasin (2014), Tiedemann and Uwe (2012) regarding the efficiency of organic and conventional farming techniques which concluded that the efficiency of farming techniques in conventional land is higher in organic farming.This means that rice farmers who do not return straw to rice fields in the study area have allocated their input use proportionally and achieved high managerial skills.While the behavior of farmers who return straw to rice fields in using input is still varied seen from inorganic fertilizers, and pesticides.In the use of inorganic fertilizers and pesticides, rice farmers who return straw to rice fields use more than those who do not return.The use of inorganic fertilizers and pesticides on farmers who return straw to rice fields means that they have exceeded the technical standards set by the government, in this case the Ministry of Agriculture.In addition to reflecting on the achievements achieved by farmers, the high level of efficiency also reflects that the opportunities to 
increase high productivity are smaller because the gap between the level of productivity that has been achieved with the maximum production level that can be achieved with the best practiced system is quite narrow. (Sumaryanto 2003).

With the average production level per hectare achieved at this time, the opportunity to increase maximum production without changing the technology in rice farming that returns straw to rice fields is $5 \%$ [1- $(0.93$ / 0.98)] higher than in rice farming that does not return straw to rice fields, which is $4 \%$ [1- (0.95/ 0.99)].This means that there is still a potential or opportunity of $5 \%$ in rice farming farmers who return straw to rice fields to increase production without changing the technology where the current average production is 54.25 quintals per hectare.While the opportunity to increase rice production by farmers who do not return straw to rice fields is only $4 \%$ where the current average production is 51.33 quintals per hectare.

The average level of technical efficiency of farming both farmers who return straw or not, has a high level of technical efficiency of $93 \%$ and $95 \%$.The high level of technical efficiency of the respondent farmers is very reasonable considering that on average they are farmers who have decades of experience in rice farming.In line with the opinion of Suharyanto et al (2015) that the experience of farmers can be used as an opportunity to direct the use of production inputs efficiently because farmers carry out farming activities based on experience.

In Table 3, it can also be seen that the technical efficiency of rice farming that returns straw to rice fields is lower than those who do not return, this is due to the return of straw on the respondent farmers have not been able to reduce the amount of production inputs, especially inorganic fertilizers due to the technology of returning straw to rice fields only have been done for two growing seasons and without the composting process.Whereas if the return of straw is carried out continuously through the composting stage it will reduce the need for inorganic fertilizers as stated by Arafah and $\mathrm{M}$. Sirappa (2002) that there is no need to fertilize using SP-36 and KCL on land that has been given insitu straw compost for three growing seasons in a row.

The distribution of allocative efficiency in rice farmers who returned straw to rice fields and those who did not return (Table 3) shows that rice farmers who returned straw to rice fields and who did not return were not allocatively efficient.As stated by Saptana (2012) that the value of allocative efficiency above 0.7 means that certain commodity farming is efficient.The average value of allocative efficiency in rice farming that returns straw is $73 \%$, while the average allocative efficiency in rice farming of farmers who do not return straw is $59 \%$.Farmers who are not allocatively efficient have been suspected because farmers have not used an optimal combination of inputs to minimize the costs of farming.However, when comparing the level of allocative efficiency achieved by farmers, the allocative efficiency of farmers in rice farming farmers who return straw is higher than those who is not returning.This shows that rice farmers who return straw use a combination of inputs in a more optimal proportion at the minimum cost level so that income becomes more optimal.Maximum income is also obtained from rice production farmers who return straw that is more optimal than rice production that does not return see in Table 3.

The use of more minimum costs in rice farming farmers who return straw is allegedly because farmers use less seeds and organic fertilizers to minimize costs compared to rice farmers who do not return.Allocative efficiency improvements that must be attempted on rice farming farmers who return straw are $26 \%$ [1-(0.73/0.99)], while in rice farming farmers who do not return straw are 39\% [1-(0.59/0,96)].

Economic efficiency is a combined effect of technical efficiency and allocative efficiency so that farming can be economically efficient if technical efficiency and allocative efficiency have been achieved.Achieving higher economic levels will increase farmers' income and profits.

When comparing the distribution of economic efficiency values from Table 3, rice farming that returns straw to rice fields is more economically efficient (average $\mathrm{EE}=70 \%$ ) than rice farming that does not return (average $\mathrm{EE}=60 \%$ ). This shows that rice farming that returns straw gives more benefits than rice farming that does not return.The use of more efficient amounts of inorganic fertilizers and also higher yields of rice production is the cause of higher returns on farmers' rice farming that returns straw.Economic efficiency in rice farming farmers who return straw can be increased again through easier efforts such as giving higher price incentives to rice farmers who return straw as an award in producing rice that uses straw as an organic fertilizer material known to labor intensive.At the research location, the price of rice that returned straw and those who did not return was not much different if it was sold to a collection trader, which ranged between Rp 5,053 / kg and Rp 5,001 / kg.

\section{Conclusions and Suggestions}

\subsection{Conclusions}

The level of technical efficiency of farmers who return straw to rice fields is $93 \%$ and those who do not return is $95 \%$, the level of allocative efficiency of farmers who return straw to rice fields is $73 \%$ and those who do not return is $59 \%$, and the level of economic efficiency of farmers who return straw to rice fields is $67 \%$ and those who do not return is $56 \%$.The level of allocative and economic efficiency of farmers who return straw to rice fields shows an increase compared to those who do not return.

\subsection{Suggestions}

Efforts should be made to strengthen farmer group institutions that are more synergized with Field Agriculture Extension so as to encourage programs that focus on local wisdom to utilize rice straw waste into rice fields as organic fertilizer.Further research needs to be done on farmers who have done composting first. 


\section{References}

i. Adiningsih, J.S., Moersidi S., Sudjadi, and A.M. Fagi. 1986. Evaluasi Status Hara Kalium Pada Lahan Sawah Intensifikasi di Jawa. Page 45-57 in Prosiding Lokakarya Nasional Efisiensi Pengunaan Pupuk. Cipayung.July7th 1986.

ii. Amrah, M. L. 2008. Pengaruh manajemen jerami terhadap pertumbuhan dan produksi padi sawah (Oryza sativa L.). Undergraduate thesis. Faculty of Agriculture, Bogor Agricultural Institute. Bogor.

iii. Arafah., S. Saenong., N. Razak., H. Tabrang and Abd Fattah. 2001. Pengkajian dan Irigasi Berdasarkan Pengelolaan Tanaman dan Suberdaya Terpadu di Sulawesi Selatan. Balai Pengkajian Teknologi Pertanian Sulawesi Selatan. Badan Penelitian dan Pengembangan Pertanian. Assessment Report.

iv. Arafah and M. Sirappa. 2002. Kajian Penggunaan Jerami dan Pupuk N, P dan K pada Lahan Sawah Irigasi. Ilmu Tanah dan Lingkungan. BPTP Sulawesi Selatan

v. Asogwa, Joseph, and Simon. 2011. Economic Efficiency of Nigerian Small Scale Farmers.J Economics,2(2) : 89-98 (2011).

vi. Balai Besar Penelitian Tanaman Padi.2015.Pengertian Umum Varietas, Galur, Inbrida, dan Hibrida.Balitbangtan. Kementrian Pertanian.Jakarta

vii. Ban, AW Van Den. dan HS. Hawkins. 2000. Penyuluhan Pertanian. Yogyakarta Kanisius.

viii. Bandura, A. 1977. Social Learning Theory. Englewood Cliffs, NJ. Prentice Hall

ix. Beattie BRand CR Taylor. 1985. The Economics of Production. New York (USA). Wiley.

x. BPS Kabupaten Subang. 2016. Subang dalam angka. BPS Subang.

xi. BPS Kabupaten Subang. 2017. Subang dalam angka. BPS Subang.

xii. BPSJawa Barat. 2016. Perbandingan Luas Panen Padi (Ha) Menurut Jenis di Jawa Barat Tahun 2013 - 2015. Berita resmi Startistika no. 38/ 07/32/ tahun XVIII, July 1st 2016.

xiii. Coelli, T. 1996. A Guide to FRONTIER Version 4.1: A Computer Program for Stochastic Frontier Production and Cost Function Estimation. Centre for Efficiency and Productivity Analysis. University of New England. Armidale

xiv. Debertin, D. L. 1986. Agricultural Production Economics. Macmillan Publishing Company. New York.

xv. Dinas Pertanian Jawa Barat. 2007. Rekomendasi Penggunaan Pupuk Propinsi Jawa Barat.

xvi. Ghozali, Imam. 2011. Aplikasi Analisis Multivariate Dengan Program SPSS. Semarang: Badan Penerbit Universitas Diponegoro.

xvii. Gujarati DN. 1993. Ekonometrika Dasar. Jakarta. Erlangga.

xviii. Haryani D. 2009. Analisis Efisiensi Usahatani Padi Sawah Pada Program Pengelolaan Tanaman dan Sumberdaya Terpadu di Kabupaten Serang Provinsi Banten. Thesis. Graduate. Bogor. Bogor Agricultural Institute.

xix. Heady EO and Dillon JL. 1964. Agricultural Production Functions. IOWA (US). Ames Iowa State Univ Press.

xx. Mardikanto, Totok. 1993. Penyuluhan Pembangunan Pertanian. Surakarta. Sebelas Maret University Press.

xxi. Mardikanto, Totok. 1996. Penyuluh Pembangunan Kehutanan. Jakarta. Pusat Penyuluhan Kehutanan Departemen Kehutanan RI in collaboration withFaculty of Agriculture, Sebelas Maret University (UNS).

xxii. Mardikanto, Totok. 2010. Komunikasi Pembangunan (Acuan Bagi Akademisi, Praktisi dan Peminat Komunikasi Pembangunan). Surakarta. UNS Press.

xxiii. Mubyarto. (1989). Pengantar Ekonomi Pertanian. Jakarta. LP3S.

xxiv. Myint, T. and T. Kyi. 2005. Analysis of Technical Efficiency of Irrigated Rice Production System in Myanmar. Presented in: Conference on International Agricultural Research for Development, Stuttgart-Hohenheim, October 11-13, 2005. .

xxv. Nugroho,N. 2011. Perbaiki Kesuburan Tanah Melalui Pengembalian Jerami Padi. Balai Pengkajian Teknologi Pertanian Jambi.

xxvi. Nunung Kusnadi, Netti Tinaprilla, Sri Hery Susilowati, dan Adreng Purwoto. 2011. Analisis Efesiensi Usaha Tani Padi di Beberapa Sentra Produksi Padi di Indonesia. Jurnal Agro Ekonomi. vol 29 No. 1 May 2011.

xxvii. Ray, Debraj. 1998. Economics Development. Princeton University Press.

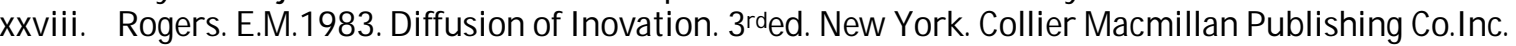

xxix. Rosinta Br. Sitepu. 2013. Pemanfaatan Jerami Padi sebagai Pupuk Organik untuk Meningkatkan pertumbuhan dan produksi padi. Department of Soil Science and Land Resources, Faculty of Agriculture, IPB

xxx. Sadono Sukirno. 2000. Pengantar Teori Mikroekonomi. Raja Grafindo Jakarta.

xxxi. Salvator D. 2005. Managerial Economics. Salemba Empat Publisher. Jakarta.

xxxii. Saptana. 2012. Konsep efisiensi Usahatani Pangan dan Implikasinya bagi Peningkatan Produktivitas. Pusat Sosial dan Kebijakan Petanian Bogor.

xxxiii. Silvira. 2012. Analisis Faktor-faktor yang Mempengaruhi Produksi Padi Sawah (studi kasus: Desa Medang Kecamatan Medang Deras)

xxxiv. Soehardjo Dan Patong, D. 1999. Sendi-Sendi Proyek Ilmu Usaha Tani. Department of Social Sciences. Bogor Agricultural Institute.

xxxv. Soekartawi. 1993. Agribisnis Teori dan Aplikasinya. Raja Garfindo Persada.Jakarta. 2003. Teori Ekonomi Produksi. Raja Grafindo Persada. Jakarta.

xxxvi. Suharyanto, Jangkung H. Mulyo, Dwidjono H. Darwanto dan Sri Widodo. 2015. Analisis Produksi dan Efisiensi Pengelolaan Tanaman Terpadu Padi Sawah di Provinsi Bali. Jurnal Pengkajian dan Pengembangan Teknologi Pertanian Tanaman Pangan Vol. 34 No. 22015

xxxvii. Sugito, Y., Yulia N, dan Ellis N. 1995. Sistem Pertanian Organik. Faculty of Agriculture, Brawijaya University. Malang. 
xxxviii. Sugiyono. 2012. Metode Penelitian Administrasi. Bandung. Alfabeta Publisher.

xxxix. Sumarno dan Unang G. Kartasasmita. 2012. Kesiapan Petani Menggunakan Pupuk Organik Padi Sawah. Pusat Penelitian dan Pengembangan Tanaman Pangan. Bogor.

xl. Sumaryanto, Wahida dan Masdjidin Siregar, 2003. Determinan Efisiensi Teknis Usahatani Padi di Lahan Sawah Irigasi. Jurnal Agroekonomi. Vol 21 No. 1, May 2003. Pusat Penelitian dan Pengembangan Sosial Ekonomi Pertanian. Bogor. Page 72-96.

xli. Suriadikarta dan Simanungkalit, 2006. Pupuk Organik dan Pupuk Hayati. Balai Besar Penelitian dan Pengembangan Sumberdaya Lahan Pertanian. Bogor.

xlii. Tien. 2010. Analisis Efisiensi Teknis Usaha Tani Padi Sawah Aplikasi Pertanian Organik di Kabupaten Malang MT 2009-2010. Malang. Dissertation. Brawijaya University.

xliii. Tim PTT Balitpa, 2001. Penggunaan Kompos Jerami Menunjang Program Pengelolaan Tanaman Terpadu. Balitpa Sukamandi. 